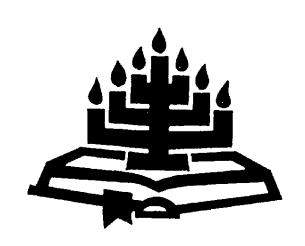

\title{
Grense tussen kerk en staat vir die reëling van die predikantsdiens: gesien vanuit twee kerkregtradisies
}

\author{
J. Smit \\ Skool vir Kerkwetenskappe \\ Potchefstroomkampus \\ Noordwes-Universiteit \\ POTCHEFSTROOM \\ E-pos: johannes.smit@telkomsa.net
}

\begin{abstract}
Boundaries for church and state regarding the regulation of the ministry of the Word: seen from two church polity traditions

This article focuses on the boundaries for church and state with regard to the regulation of the ministry of the Word - seen from two independent church polity traditions. Until now the South African courts have not given an indication of how these boundaries should be understood or how these apply within the South African context. The purpose of this article is not to make a judicial comparison. The purpose is to show that two independent church polity traditions, namely the German and the reformed, developed general principles for the boundaries of church and state with regard to the regulation of a minister's position in law. In both traditions church polity is regarded sui generis, and recognises the church's right to regulate a minister of religion's position independently from the state. In conclusion it is found that the boundaries between church and state for the ministry of the Word are primarily determined by the principle that church and state should not in any way influence or interfere with one another's separate mandates or duties. The ministry of the Word is the responsibility of the church and not the state. Therefore the state does not have the competency to regulate the ministry of the Word.
\end{abstract}




\section{Opsomming}

\section{Grense tussen kerk en staat vir die reëling van die predikantsdiens: gesien vanuit twee kerkregtradisies}

In hierdie artikel word gefokus op grense tussen die kerk en die staat vir die reëling van die predikantsdiens - gesien vanuit twee onafhanklike kerkregtradisies. Hierdie grense is nog nie duidelik deur die Suid-Afrikaanse howe omlyn nie. Die doel van hierdie artikel is nie 'n regsvergelykende studie nie. Die doel is om aan te toon dat twee onafhanklike kerkregtradisies, naamlik die Duitse kerkreg en die gereformeerde kerkreg, vanuit 'n historiese ontwikkelingsgang algemene beginsels ontwikkel het wat grense vir die staat se reëlingsbevoegdheid stel met betrekking tot die reëling van die gereformeerde predikantsdiens en wat die kerk se eie bevoegdheid in hierdie verband as 'n eiesoortige (sui generis) reg daarstel. Die kernbevinding van hierdie artikel is dat die grense tussen die kerk en die staat vir die predikantsdiens primêr daardeur bepaal word dat die kerk en die staat nie enige invloed op mekaar se onderskeie opdragte en take mag uitoefen nie. Die predikantsdiens is die sentrale opdrag van die kerk en nie van die staat nie. Die staat het dus nie die reëlingsbevoegdheid vir die predikantsdiens nie.

\section{Inleiding}

\section{1 'n Woord vooraf}

Dit is ' $n$ voorreg om hierdie artikel by die geleentheid van professor A. le R. du Plooy se emeritering as hoogleraar aan die Teologiese Skool Potchefstroom te publiseer. Professor Du Plooy het hom in die jare voor sy emeritering toegespits op navorsing oor die kerkstaatverhouding - spesifiek die verhouding tussen die kerkorde (kerkregering) en die grondwet (staatsregering). Uit professor Du Plooy se publikasies blyk sy liefde vir die kerk as die liggaam van Christus. Onlosmaakbaar daaraan verbind, is die besorgdheid dat die kerk na sy oorsprong, wese en doel die geleentheid moet hê om waarlik kerk te wees in 'n gegewe staatkundige opset. Professor Du Plooy se bydrae word onder meer daarop gegrond dat daar grense gestel is vir die kerk en die staat se reëlingsbevoegdheid. In hierdie artikel word die grense tussen kerk en staat vir die reëling van die predikantsdiens - gesien vanuit twee kerkreg tradisies, verder uitgewerk. Hierdie artikel is 'n huldigingsblyk aan 'n buitengewone leermeester en gewaardeerde vriend. 


\subsection{Aktualiteit en doelstelling}

Die aktualiteit van hierdie navorsing rus daarop dat die howe in Suid-Afrika nog nie duidelike grense vir die kerk en die staat bepaal het met betrekking tot die reëling van die predikantsdiens nie. Hofuitsprake het eerder tot verwarring by kerke aanleiding gegee oor 'n saak wat die kerk in sy wese raak. In Schreuder v. Die Nederduitse Gereformeerde Kerk Wilgespruit e.a. 199920 ILJ 1936 (LC) en in Church of the Province of Southern Africa (Diocese of Cape Town) v. CCMA \& others [2001] 11 BLLR 1213 (LC) het die howe byvoorbeeld teenoorstaande bevindings oor die predikantsdiens gemaak. Die hof het in die Schreuder-saak bevind dat die arbeidswetgewing op die predikantsdiens van toepassing is. Sodoende word die grense tussen die kerk en die staat de facto opgehef (vgl. Smit, 2001:74-78). In die Church of the Province of Southern Africa (Diocese of Cape Town)-saak het die hof bevind dat die arbeidswetgewing nie op 'n predikant/priester van toepassing is nie. In albei sake was dit 'n kernvraag of die predikantsdiens by wyse van 'n kontraktuele verhouding gereël word (Schreuder v. Die Nederduitse Gereformeerde Kerk Wilgespruit e.a. 199920 ILJ 1936 (LC) par. 18 en 25; Church of the Province of Southern Africa (Diocese of Cape Town) v. CCMA \& others [2001] 11 BLLR 1213 (LC) par. 32 en 36). Die indruk kan geskep word dat die grense tussen die kerk en die staat met betrekking tot die predikantsdiens slegs bepaal word deur die vraag of daar 'n kontraktuele verhouding tussen die predikant en die kerkraad is.

Hierdie benaderingswyse van die howe bied nie 'n bevredigende antwoord nie. Verskeie navorsers het aangetoon dat Suid-Afrika sinvol by ander jurisdiksies kan aansluit om grense tussen die kerk en die staat vir die reëling van die predikantsdiens te bepaal (Olivier, 2002:530-542; Coertzen, 2002:410). In hierdie artikel word aansluiting gevind by die Duitse benadering met betrekking tot die reëling van die predikantsdiens. Duitsland is, soos Suid-Afrika, 'n regstaat wat 'n godsdiensonpartydige oftewel godsdiensneutrale 1 uitgangspunt teenoor die kerk handhaaf. Die doel van hierdie artikel is nie 'n regsvergelykende studie nie. Die doel is om aan te toon dat twee onafhanklike kerkregtradisies, naamlik die Duitse kerkreg en die gereformeerde kerkreg, vanuit 'n historiese ontwikkelingsgang

1 In Suid-Afrika word voorkeur gegee aan die term godsdiensonpartydige staat. Vanweë die aansluiting by die Duitse benadering word godsdiensneutrale staat egter by voorkeur gebruik. Laasgenoemde is 'n geykte term in die Duitse Staatskerkreg. 
algemene beginsels ontwikkel het wat grense vir die staat se reëlingsbevoegdheid stel met betrekking tot die reëling van die gereformeerde predikantsdiens en wat die kerk se eie bevoegdheid in hierdie verband as 'n eiesoortige (sui generis) reg daarstel.

\section{Grense tussen kerk en staat: historiese ontwikkelingsgang}

\subsection{Flitse vanuit die Reformasie}

Die hedendaagse beskouing dat daar grense tussen die kerk en die staat is, word in die sestiende- en sewentiende-eeuse Reformasie begrond. Die reformatore, spesifiek Martin Luther (1483-1546) en Johannes Calvyn (1509-1564), het tussen die regeringsbevoegdheid van die kerk en die staat onderskei. In breë terme kan daar na Luther en Calvyn se beskouings verwys word as 'n twee ryke-leer (Heckel, 1994:177). Volgens die twee ryke-leer het die staat die reëlingsbevoegdheid vir die burgerlike regering, terwyl die kerk vir die geestelike regering verantwoordelik is. Kerk en staat is dus twee afsonderlike entiteite met die inherente gesag om afsonderlik van mekaar te regeer. Die een entiteit herlei nie sy gesag van die ander nie (Van der Vyver, 2002: part 1; vgl. Smit, 1985:81 e.v.).

Die standpunte van die reformatore was gerig teen die teologie van die Rooms-Katolieke Kerk, oftewel die middeleeuse beskouing. Kerk en staat is in die Middeleeue nie formeel van mekaar geskei nie, maar in 'n geestelik-juridies bepaalde eenheid as gesagsinstellings van mekaar onderskei (Schlaich, 1972:28). Daar is byvoorbeeld nie 'n diepgaande onderskeid tussen die bronne vir die kerkreg en die reg gemaak nie. Die ius divinum (Goddelike reg soos verwoord in die Skrif) is as basis vir die kerkreg en die reg gebruik. Die reg, staat en staatsowerheid het volgens hierdie beskouing gesamentlik in diens van die Goddelike waarheid gestaan (Schlaich, 1972:28). Hierteenoor het die reformatore die beskouing gehandhaaf dat die kerk nie met die staat vergelykbaar is, gelykgestel of in regering vereenselwig kan word nie (vgl. Heckel, 1994:181, 183). Die reformatore het egter nie ontken dat die staatsowerheid deur God ingestel is nie. Vanweë die kerk en die staat se unieke oorsprong, wese, doel en regeringswyse is daar wel grense gestel aan die reëlingsbevoegdheid van die kerk en die staat (vgl. Heckel, 1994: 181, 183).

Volgens Calvyn verskil die staatsregering van die kerkregering daarin dat die staatsregering 'n "uiterlike" regering is en die kerkregering 'n "innerlike" (geestelike) regering (Calvyn, 1991:4.3.1; 4.3.1, 
voetnoot 1; 4.20 .1 e.v.) Verder wys Calvyn daarop dat daar nie 'n "botsing" tussen die kerk en die staatsregering is nie. Calvyn het byvoorbeeld ' $n$ teokratiese staatsmodel ontwikkel sonder om die grense tussen die kerk en die staat op te hef (Calvyn, 1991:4.20.4 e.v.). Die kerk is, in onderskeid van die staat, as 'n godsdienstige instelling gedefinieer wat op 'n unieke wyse onder die koningskap van Christus funksioneer (Smit, 1985:81). Die koningskap van Christus oor die kerk is in die gereformeerde kerkreg, en sedert 1948 ook in die Duitse kerkreg en staatskerkreg, ontwikkel as die grondbeginsel vir die skeiding tussen die kerk en die staat (Van der Walt, 1976:28 e.v.; Smend, 1951:9). Hierdie beginsel is eweneens die basis waaruit die kerk as 'n eiesoortige (sui generis) gemeenskap in die samelewing met 'n eiesoortige reg (sui generis) gedefinieer word (Robbers, 2001:649). Die erkenning van die eiesoortige aard van die kerk en die kerkregering is derhalwe rigtinggewend vir die bepaling van die grense tussen die kerk en die staat.

Die bydrae van die reformatore in hierdie verband mag nie gering geskat word nie. Basiese vertrekpunte vir die hedendaagse beskouing oor die grense tussen kerk en staat is deur die reformatore verwoord. Sodoende bied die reformatore se beskouings steeds 'n geldige vertrekpunt vir kerkregtelike studie oor die grense tussen kerk en staat. In die geheel gesien, bied hierdie beskouings egter nie die finale antwoord vir die problematiek van die hedendaagse kerk-staatverhouding nie. Sommige regsgeleerdes is egter wel van mening dat dit as 'n verlies aangeteken moet word dat die reformatore se beskouings oor die verhouding tussen kerk en staat nie in die ontwikkeling van die regsfilosofie tot die volle kapasiteit daarvan uitgebou is nie (Heckel, 1994:185).

\subsection{Flitse vanuit die regsfilosofie}

\subsubsection{Frankryk}

Die sestiende- en sewentiende-eeuse Reformasie het in Frankryk 'n kookpot van opponerende godsdienstige standpunte veroorsaak. Frankryk was nie, soos Duitsland, by wyse van 'n federale staatstelsel georganiseer nie ${ }^{2}$ (vgl. Pirson, 1994:13 e.v.). Verskillende godsdienstige groepe kon hulle derhalwe nie in territoriaal bepaalde

2 Die term federale stelsel word hier gebruik om die verbintenis tussen die verskillende territoriale gebiede in die sestiende-eeuse Duitsland aan te toon. In die hedendaagse gebruik van die woord was Duitsland, streng gesproke, nie in daardie tydperk 'n federasie nie. 
vorsdomme skaar nie. Die kernvraag wat beantwoord moes word, was hoe die staat die politieke eenheid kon handhaaf te midde van diepliggende geloofsgeskeidenheid. Op hierdie vraag het die Erastiaanse Humanisme nie 'n blywende politieke antwoord gebied nie (Schlaich, 1972:31). Die antwoord is vanuit die geledere van die sogenaamde politiques ontwikkel. Die politiques was 'n derde groepering naas die Rooms-Katolieke Kerk en die protestante. Die kanselier van Frankryk, Michel de Hospital, het die gedagtegang van die poltiques soos volg verwoord:

Der König will nicht, das ihr um die bessere Meinung streitet; denn nicht de constituenda religione sed de constituenda republica steht hier in Frage; selbst der Exkommunizierte hört nicht auf, Staatsbürger zu sein. Kann man denn in Ruhe leben mit denen, die verschiedener Meinung sind? (Schlaich, 1972: 32.)

Die politiques se beskouing het die eenheid van die staat bo die eenheid in geloofsbelydenis gestel. Hierdie benadering gaan van die veronderstelling uit dat daar grense tussen die kerk en die staat is. Die grense tussen kerk en staat het ten doel dat die kerk en die staat vry van mekaar kan funksioneer. Die Edik van Nantes (1598) was byvoorbeeld 'n poging om aan 'n spesifieke groep, naamlik die geesgenote van koning Hendrik IV, 'n beperkte mate van godsdiensvryheid te gee. Die volle impak van hierdie ontwikkeling is egter eers ná die Franse burgeroorlog op die kerk-staatverhouding toegepas. Dit was die gevolg daarvan dat die politiques se ordebegrip 'n fundamentele tekortkoming gehad het (Schlaich, 1972:33, 34). Hierdie ordebegrip is in die plek van die Rooms-Katolieke en reformatoriese beskouings gestel. Die politiques se ordebegrip het die politiek losgemaak van godsdiens (middeleeuse beskouing) en het ook die reformatoriese kerk- en wêreldbeskouing verwerp (Heckel, 1994:178, 179). Hierdie beskouing het 'n vakuum in die staatsorde geskep - 'n Inhaltlich entleerten Legalität (Schlaich, 1972:36). Sodoende is die moontlikheid geskep dat 'n persoon of groep se beskouing deurslaggewend kon wees vir beslissings. Entscheidend ist, $d a \beta$ entschieden wird - totdat 'n nuwe konflik of uitsonderlike situasie die geleentheid bied wat 'n nuwe besluit daaroor regverdig (Schlaich, 1972:35).

Die vakuum in die politiques se staatsordebegrip is deur die "toevallige" en "willekeurige" opinie van die staatshoof (koning) gevul. Lodewyk XIV kon derhalwe die Edik van Nantes ophef en voortgaan met die vervolging van die protestante. Hierdie eensydige beskouing op die kerk is deur die Franse rewolusie voortgesit. Die Franse 
Rewolusie wou die staat self laat kerk wees - La Révolution ... était une église ellemême (Schlaich, 1972:34, voetnoot 134). Hierdeur is ' $n$ radikale laisistiese benadering teenoor die kerk ontketen, wat vandag steeds 'n kenmerk is van die Franse staat se benadering teenoor godsdiens (Von Campenhausen, 1994:66-68; Heckel, 1994:178). Eers tydens die Franse burgeroorlog het die besef ontwikkel dat die politieke vrede slegs gehandhaaf kan word indien die strydende partye hulle gemeenskaplik aan die wet onderwerp (Schlaich, 1972:36). So is die basis vir die ontwikkeling van die hedendaagse regstaat gelê - 'n kernaspek vir 'n hedendaagse beskouing van die grense tussen die kerk en die staat.

\subsubsection{Duitsland}

In Duitsland het die Reformasie eweneens 'n stryd ontketen wat, soos in Frankryk, die moontlikheid van 'n rykskeuring ingehou het. Verskeie partye het aan hierdie stryd deelgeneem, byvoorbeeld die keiser, die landshere, die onderskeie politieke stande en die geestelikes. Hierdie onderskeie groeperings het die Reformasie nie beskou as 'n rewolusionêre poging om die staatsowerheid omver te werp nie. In Duitsland het die Rooms-Katolieke Kerk en die reformatore hoofsaaklik binne die grense van bepaalde wette gestry vir die aanvaarding van 'n spesifieke teologiese waarheidsbeskouing (Schlaich, 1972:28, 29). Die wet het sodoende 'n sentrale plek ingeneem - die vrede tussen die strydende godsdienstige groepe kon slegs by wyse van die handhawing van die wet gewaarborg word. Religions-Fried non est res spiritualis, sed politica et secularis, et ex nullo alio iure quam ex iuris regulis. ${ }^{3}$ (Schlaich, 1972:30, 31.) Die sentrale plek wat in Duitsland aan die wet gegee is, het die moontlikheid geskep dat die onderskeie godsdiensgroepe se gelykheid voor die reg vroeg in hierdie ontwikkelingstydperk erken is. Die strydende groepe het tot die besef gekom dat die staat en die godsdiensgroepe in verdraagsaamheid teenoor mekaar kan saamleef onder die gesag van die wet (vgl. Von Campenhausen, 1994: 55).

Die Reformasie het 'n fundamentele breuk met die Rooms-Katolieke Kerk se beskouing van die staat ingehou. Volgens die middeleeuse beskouing in Duitsland het die eenheid van die staat op 'n godsdienstig-konfessionele eenheid gerus. Hierdie eenheidsbegrip

3 "Godsdiensvrede is nie 'n geestelike saak nie, maar 'n staats- en sekulêre saak, en volgens geen ander reg as uit regsbeginsels nie." 
van die Rooms-Katolieke Kerk is met die beskouing vervang dat die staat slegs op 'n politieke eenheid rus. Die staat het dus nie 'n belang by godsdiens nie, maar neem die plek van 'n "onpartydige derde party" in - 'n neutrale vlak vanwaar die staat die landsvrede kan waarborg (Schlaich, 1972:29, 30). Hierdeur het die behoud van politieke vrede en eenheid voorrang verkry bo die konfessioneelbepaalde waarheidsvraag van die godsdienstige groepe. Die staat mag dus nie standpunt inneem of 'n invloed uitoefen op eksegetiesdogmatiesbepaalde aangeleenthede nie. Die gevolg was dat daar 'n onderskeid tussen die landsvrede en die godsdienstige vrede gemaak is. Die godsdienstige vrede van die staat het nie meer die politieke vrede bepaal nie. Die politieke vrede is eweneens nie meer op 'n godsdienstig-konfessionele eenheid begrond nie.

Der Landfriede bietet eine Ebene politischer Neutralität; das Friedensgesetz brachte eine offene und dauerende Abschichtung der politisch-rechtlichen Existenz vom religiösen Bereich, eine Abschließung des Rechts gegëber dem Absolutheits anspruch der Theologie. (Schlaich, 1972:30.)

\subsection{Perspektief}

Die voorafgaande uiteensetting bied die volgende insigte:

- Die ontwikkeling van grense tussen die kerk en die staat is 'n gevolg van die godsdienspluralisme wat tydens die Reformasie van die sestiende en sewentiende eeu ontstaan het. Die grense tussen die kerk en die staat veronderstel dat die staat 'n soewereine instelling is wat die gesag het om die politieke vrede te handhaaf en nie daarvoor verantwoordelik is om godsdienstige of konfessioneel-kerklike eenheid te handhaaf nie.

- Die grense tussen kerk en staat vind prakties uitdrukking in eerstens, die vestiging van 'n godsdiensneutrale regstaat; tweedens, die handhawing van vryheidsregte (byvoorbeeld die skeiding tussen die kerk en die staat, godsdiensvryheid en die uitlewing daarvan) vir die kerk; en derdens, die erkenning deur die staat dat die kerk as 'n selfstandige gemeenskap in die samelewing funksioneer.

- Die grense tussen die kerk en die staat word fundamenteel bepaal deur tussen die verskillende opdragte en take van die kerk en die staat te onderskei. Kerk en staat het nie die bevoegdheid om wedersyds op mekaar se opdragte en take seggenskap uit te oefen nie. Die staat mag dus ook nie enige seggenskap uitoefen op sake wat konfessioneel bepaal word nie. 


\section{Grense tussen kerk en staat: Duitse benadering}

\subsection{Ontwikkeling sedert die era van die staatskerk}

Tydens die staatskerkera in Duitsland het predikante basies as staatsbeamptes gefunksioneer. In hierdie era was daar hoofsaaklik een primêre bron waarvolgens die predikantsdiens gereël is, naamlik die Weimarer Reichsverfassung (WRV). Die howe het ook die "historiese ontwikkeling" van die Weimarer Reichsverfassung in ag geneem vir 'n beoordeling van die predikantsdiens (Pirson, 1995: 845, 846). Die "historiese ontwikkeling" verwys na die kanoniese reg én kerkordes, wat sedert die Reformasie onder die gesag van die relevante staatsoutoriteite opgestel is. Sedert die aanvaarding van die Bonner Grundgesetz (BG) in 1948 is die vraag gestel of die staat werklik die bevoegdheid het om die predikantsdiens te reël, aangesien die Bonner Grundgesetz bepaal dat daar 'n skeiding tussen die kerk en die staat gehandhaaf word. Die vraag was of die skeiding tussen kerk en staat nie ook 'n grens aan die staat se reëlingsbevoegdheid vir die predikantsdiens stel nie (Pirson 1995:846). Tans word in Duitsland aanvaar dat die staat nie die bevoegdheid het om die predikantsdiens te reël nie. Slegs die kerk het die reëlingsbevoegdheid vir die predikantsdiens (BVerfGE 42 (312 e.v.)). 4

Hierdie beskouing word onder meer op grondwetlike bepalings gegrond, soos byvoorbeeld die skeiding tussen kerk en staat, die kerk se reg tot kerklike selfverwesenliking, 5 én die kerk se reg van godsdiensvryheid en die uitlewing daarvan (vgl. Von Campenhausen, 1994:77). Volgens die Duitse staatskerkreg is hierdie bepalings 'n belangrike raamwerk om te bepaal wie van die kerk of die staat die reëlingsbevoegdheid vir die predikantsdiens het, al dan nie (vgl. Rüfner, 1995:878; Pirson, 1995:903-904). 'n Kernpunt is egter dat die toepassing van een of albei van hierdie regte nie die essensie van die saak aanraak nie. Die kerk se reg om die predikantsdiens te reël, berus byvoorbeeld nie slegs daarin dat die staat by wyse van bepalings oor godsdiensvryheid die vryheid aan die kerk bied om hierdie diens te reël nie (vgl. BVerfGE 70, 138 (164 e.v.)). So 'n vryheid het elke werkgewer. 'n Werkgewer bepaal immers die opdrag wat die werknemer moet uitvoer na gelang van sy voorkeur

$4 \quad$ BVerfGE is die akroniem vir Entscheidungen des Bundesverfassungsgerichts.

5 Selbstbestimmungsrecht word in hierdie artikel vertaal met die reg van kerklike "selfverwesenliking" (vgl. Hesse, 1994:521-559). 
in 'n kontrak (Pirson, 1995:847). Die kerk se reg om die predikantsdiens te reël kan ook nie slegs toegeskryf word aan die kerk se reg van kerklike selfverwesenliking nie. Dit sou beteken dat die predikantsdiens bloot as een van vele aangeleenthede beskou word waarvoor die kerk die reëlingsbevoegdheid het (Pirson, 1995:847). Die misverstand kan ontstaan dat die kerk die reëlingsbevoegdheid vir die predikantsdiens het vanweë 'n vergunning van die staat aan die kerk. Dit hou die moontlikheid in dat die kerk se inherente selfstandige gesag om die predikantsdiens te reël, ontken word (BVerfGE 18, 385 (386 e.v.)).

Volgens die Duitse staatskerkreg word die grens vir die staat met betrekking tot die reëling van die predikantsdiens vanuit die ontwikkelingsgeskiedenis van die hedendaagse staat bepaal. Die grens word bepaal deur te fokus op die onderskeie opdragte en take van die kerk en die staat. Die staat mag die Evangelie “... nicht hervorbringen, nicht stiften, nicht erhalten, nicht gewährleisten, erst recht: nicht erzwingen" (Hollerbach, 1998:34). Laasgenoemde is uitsluitlik die taak van die kerk. In die Duitse staatskerkreg word aanvaar dat predikante hulle opdragte juis ooreenkomstig die opdrag van die kerk moet uitvoer. Daarop mag die staat geen seggenskap uitoefen nie. "Einwirkungen des staatlichen Rechts auf das, was dem kirchlichen Auftrag inhaltlich ausmacht, sind deshalb für ein säkulares Staatsverständnis unvorstelbar." (Pirson, 1995:848.)

\subsection{Regspraak in Duitsland}

\subsubsection{Die konteks}

Die Kirchentag (provinsiale sinode) van die Bremische Evangelische Kirche het op 28 Maart 1973 besluit dat kerklike bedienaars (predikante en kerkbeamptes) van hierdie kerkgemeenskap verlof toegestaan word vir die tydperk waarvoor hulle verkies is om in die Bremische Bürgerschaft (munisipaliteit) te dien (BVerfGE 42, 312 $(313,314))$. Volgens die provinsiale sinode kan 'n persoon nie terselfdertyd in die predikantsdiens staan en as 'n munisipale beampte dien nie (BVerfGE 42, 312 (314)). Die munisipaliteit het hierdie besluit nie aanvaar nie. Die saak het derhalwe voor die Staatsgerichtshof gedien. Die vraag waaroor hierdie hof moes beslis, was of die besluit van die Bremische Evangelische Kirche toelaatbaar is selfs as dit teen die wil van die persoon is wat daardeur geraak word (BVerfGE 42, 312 (314)). Die Staatsgerichtshof het bevind dat die besluit van die Bremische Evangelische Kirche in die lig van tersake wetgewing, nie toelaatbaar is nie. Die Bremische Evangelische Kirche het hulle teen hierdie beslissing van die Staatsgerichtshof op 
die Bundesverfassungsgericht beroep. Die Bundesverfassungsgericht het op 21 September 1976 uitspraak ten gunste van die Bremische Evangelische Kirche gelewer (BVerfGE 42, 312 (312 e.v.)). Hierdie uitspraak dien in die Duitse staatskerkreg as 'n maastaf waarvolgens die grense tussen die kerk en die staat vir die reëling van die predikantsdiens bepaal word. Hier word gefokus op kernaspekte van die uitspraak, wat van toepassing is op die grense vir die staat se reëlingsbevoegdheid vir die predikantsdiens.

\subsubsection{Godsdiensneutrale uitgangspunt van die staat}

Volgens die Bundesverfassungsgericht is die historiese ontwikkeling van grense tussen die kerk en die staat voorskriftelik van toepassing op die tersake aangeleentheid (BVerfGE 42, 312 (330)). In Duitsland het die kerk-staatverhouding sedert die staatskerkera ontwikkel in 'n hedendaagse regstaat wat 'n godsdiensneutrale uitgangspunt teenoor kerke handhaaf. Sedert die begin van die twintigste eeu het die kerke hulle van die staat losgemaak. Hierdie proses het sedert 1945 daartoe aanleiding gegee dat die staat die kerk se selfstandigheid erken. Die selfstandigwording van die kerk het egter nie tot 'n vyandige benadering van die staat teenoor die kerke aanleiding gegee nie (BVerfGE 42, 312 (330)). Die Bundesverfassungsgericht het die staat se godsdiensneutrale uitgangspunt teenoor die kerk (godsdiens) byvoorbeeld al beskryf as 'n respekterende en versorgende neutraliteit:

Die dem Staat vom Grundgesetz auferlegte Pflicht zu weltanschauliche Neutralität sei keine distanzierende, abweizende im Sinne der laizistischen Nichtidentifikation mit Religion und Weltanschauungen, sondern eine respektierende, versorgende Neutralität, die den Staat verplichte, dem Einzelnen wie auch den Religions- und Weltanschauungsgemeinschaften einen Betétigungsraum zu sichern. Die dem Staat gebotene religiösweltanschauliche Neutralität ist indes nicht eine distanzierende im Sinne einer strikten Trennung von Staat und Kirche, aber als eine und übergreifende, die Glaubensfreiheit für alle Bekenntnisse gleichermaßen födernde Haltung zu verstehen. (BVerfG, BvR 1436/02 vom 3.6.2003 par 10.)

Die godsdiensneutrale uitgangspunt van die staat hou in dat die staat grense aan sy reëlingsbevoegdheid ten opsigte van die kerk stel (BVerfGE 42, 312 (330, 331, 332)). Die Bundesverfassungsgericht onderskei prinsipieel tussen die kerk en die staat se bevoegdheidsterreine op grond van albei instellings se onderskeie opdragte en take (vgl. BVerfGE 42, 312 (331, 334, 335)); Hesse, 1994:529). Dit beteken dat die staat slegs ten doel het om die 
burgerlike samelewing op 'n ordelike wyse te reël en nie seggenskap het oor interne kerklike reëlings nie (BVerfGE 42, 312 (331, 332)). Die staat plaas ook ' $n$ hoë premie op die erkenning en handhawing van die kerk se selfstandigheid (BVerfGE 42, 312 (331, 332)). Die kerk is ' $n$ selfstandige gemeenskap wat nie sy gesag van die staat herlei nie (BVerfGE 18, 385 (386)). Die staat erken dus die deurslaggewende belang van die kerk se taak vir die samelewing (BVerfGE 42, 312 (331, 332)). Die erkenning en verwesenliking van die kerk se selfstandigheid skep juis die moontlikheid dat die kerk sy taak beter kan uitvoer (BVerfGE 42, 312 (331)).

Volgens die Bundesverfassungsgericht beskou die kerk die skeiding tussen die kerk en die staat as 'n bevryding van afhanklikheid van die staat (BVerfGE 42, 312 (331)). Die kerke erken egter ook die onontbeerlike noodsaaklikheid van die staat se reëlingsbevoegdheid vir die burgerlike samelewing (BVerfGE 42, 312 (331)). Die kerke se selfstandigheid vind daarin uitdrukking dat hulle sonder staatsinmenging hulle godsdiensbepaalde opdrag mag uitvoer. Hierdie opdrag is nie bloot op die hiernamaals gerig nie, maar vind konkreet uitdrukking in die werklikheid (BVerfGE 42, 312 (331)). Kerk en staat beskou mekaar nie as ondergeskiktes nie, maar as vennote wat in belang van dieselfde gemeenskap optree. "Im Zeichen deutlicher Freiheit wünschen wir Partnerschaft ..." Hierdie "vennootskap" tussen die kerk en die staat vind daarin uitdrukking dat juridiese bepalings en hofuitsprake sover moontlik die beswil van kerk en staat moet dien (BVerfGE 42, 312 (331)). Dit is slegs moontlik indien die grense wat 'n godsdiensneutrale uitgangspunt aan die staat stel deur die onafhanklike regbank gehandhaaf word. Godsdiensneutraliteit stel die grens dat die staat geen invloed op die verkondigingstaak van die kerk mag uitoefen nie en juis daarom ook nie op die kerk se reëlings met betrekking tot die predikantsdiens nie.

Der Staat darf lediglich keine gezielte Beeinflussing im Dienste einer bestimmten politischen, ideologischen oder weltanschaulichen Richtung betreiben oder sich durch von inm ausgehende oder inm zuzurechende Maßnahmen ausdrücklich oder konkludent mit einem bestimmten Glauben oder einer bestimmten Weltanschauung identifizieren und dadurch den religiösen Frieden in einer Gesellschaft von sich aus gefährden. (BVerfG, BvR 1436/02 vom 3.6.2003 par 10.) 


\subsubsection{Godsdiensvryheid en die uitlewing van godsdiensvryheid}

Vervolgens het die Bundesverfassungsgericht die sogenaamde "vryheidsregte" wat deur die grondwet verskans word geïnterpreteer (BVerfGE 42, 312 (332 e.v.)). Die vryheidsregte wat deur die grondwet gewaarborg word, stel prinsipieel beoordeelde grense aan die staat se gesag. Sodoende poog die staat om die waardigheid en vryheid van die mens (burgerlike samelewing) te beskerm (BVerfGE 42, 312 (331)). Die Duitse grondwet ken nie 'n allesomvattende gesag aan die staat toe nie, maar beperk die staat se gesag tot die beskerming van die belange van staatsburgers (BVerfGE 42, 312 (332 e.v.)). Dit beteken dat die staat die verantwoordelikheid het om terselfdertyd die reg van vryheid en sosiale geregtigheid vir alle landsburgers te handhaaf. Die vryheidsregte beperk die staat om nie as die beskermer van 'n "verlossingsplan" vir die gemeenskap op te tree nie (vgl. Kirchhof, 1994:651). Verder mag die staat ook nie op enige wyse uitdrukking gee aan die geloof en denke van landsburgers nie: “... er verwehrt dem Staat den bestimmenden Zugriff auf die religiöse oder weltanschauliche Dimension des Menschen" (BVerfGE 42, 312 (332)).

Die vryheid van geloof en denke moet in verband met ander grondwetlike bepalings van die Duitse Grondwet, byvoorbeeld die reg van kerke om selfstandig van die staat te funksioneer, verstaan word. Die reg van kerklike selfstandigheid skep volgens die Bundesverfassungsgericht 'n "onaantasbare vryheidsgebied" vir die kerke (BVerfGE 42, 312 (332)). In hierdie vryheidsgebied het die kerk die alleenseggenskap oor kerklike reëlings. Die staat mag sy reëlingsbevoegdheid nie op hierdie gebied afdwing nie. Enersyds bring die erkenning en handhawing van hierdie kerklike vryheidsgebied nie die soewereiniteit van die staat in gedrang nie. Andersyds aanvaar die staat dat die geloofsmondige landsburger se vereenselwiging met 'n kerk (godsdiensgemeenskap) die moontlikheid skep dat die staat vanweë sy erkende beperkings nie die bevoegdheid het om sy reëlingsbevoegdheid op hierdie gebied af te dwing nie (BVerfGE 42, 312 (332)).

Volgens die Duitse beskouing hou die grondwet-gewaarborgde vryheidsregte twee afsonderlike aspekte in. Vryheid gee aan die kerk die reg om vry van staatsinmenging in die samelewing te funksioneer. Hierdie vryheid gee egter ook 'n spesifieke verantwoordelikheid aan die kerke. Die kerk het die verantwoordelikheid om sy vryheid nie te misbruik nie, maar onder die gesag van die grondwet uit te oefen. Kerklike vryheid en verantwoordelikheid is dus onlosmaakbaar aan mekaar verbind. Die vryheid van die kerk vind onder 
meer daarin uitdrukking dat die kerk op verantwoordbare wyse 'n keuse mag uitoefen ten gunste van die toepassing van arbeidswetgewing op die predikantsdiens, al dan nie (vgl. BVerfGE 42, 312 (332); Richardi, 2004:6, voetnoot 27). Die Rooms-Katolieke Kerk het byvoorbeeld die keuse uitgeoefen dat arbeidswetgewing nie op die predikantsdiens van toepassing is nie. Hierdie kerkgemeenskap het ook daarvoor gekies dat die predikantsdiens nie aan die hand van die Duitse staatsbeamptereg gereël word nie. Die Rooms-Katolieke Kerk reël die predikantsdiens slegs by wyse van die Codex luris Canonici (cc. 145-196, 232-293, 1740-1752); vgl. Smit, 2008:228). Hierdie keuse moet deur die howe gerespekteer word.

Die Evangeliese Kerke van Duitsland het eweneens die keuse uitgeoefen dat die arbeidsreg nie op die predikantsdiens van toepassing is nie. Vanweë die historiese vervlegtheid van staatsregtelike en kerkregtelike bepalings oor hierdie diens, reël die Evangeliese Kerke wel die predikantsdiens aan die hand van die Duitse staatsbeamptereg (Frank, 1976:718 e.v.). In die Evangeliese Kerke is daar derhalwe 'n wisselwerking tussen die kerkreg, die staatskerkreg en die staatsbeamptereg met betrekking tot die reëling van die predikantsdiens. Die grense wat die grondwet aan die reëlingsbevoegdheid van die staat stel, word nie deur hierdie wisselwerking opgehef nie (Pirson, 1995:850 e.v.). Die howe mag nie enige invloed op eiesoortige kerklike reëlings uitoefen nie. Die Evangeliese Kerke behou dus die reg voor om op grond van hulle selfdefiniëring bepalings te maak vir die reëling van die predikantsdiens. Dit beteken dat die howe nie op 'n rigiede wyse 'n regskonstruksie op die predikantsdiens mag afdwing nie. Die kerk het die reg om 'n keuse uit te oefen vir die regskonstruksie waarvolgens hulle die predikantsdiens reël. Hierdie keuse moet deur die howe gerespekteer word (BVerfGE 70, 138 (164 e.v.)).

\subsubsection{Kerklike selfdefiniëring en selfverwesenliking}

Volgens die Bundesverfassungsgericht is die reëling van die kerklike dienste 'n ganz zentralen Sachverhalts vir die kerk (BVerfGE 42, 312 (335)). Die definiëring van die kerklike dienste raak die kerk op 'n besondere wyse, naamlik in sy "anders"-wees as ander gemeenskappe (BVerfGE 42, 312 (335)). Die Evangeliese Kerke definieer die kerklike amp (diens) as "opdrag van die Here en diens van die Woord". Hierdie diens vind prakties uitdrukking in die "amp van 'n predikant van 'n gemeente". Die "godsdienstige" amp (in onderskeid met byvoorbeeld staatsbeamptes) word ooreenkomstig die belydenis van die kerk gereël. Hierdie amp konkretiseer in die bediening van die pastoraat, die Woordverkondiging, die bediening van die 
sakramente en diakonale werk (BVerfGE 42, 312 (335, 336)). Om predikant te wees beteken vir die kerke dat 'n predikant voltyds die opdrag van die Here uitvoer. Die uitvoering van 'n predikant se opdrag kan nie juridies bepaal word nie. "Die Fülle dieser Pflicht aus dem geistlichen Amt läßt sich nicht rechtlich normieren." (BVerfGE 42, 312 (336).)

Met betrekking tot die reëling van die predikantsdiens, het die hof die kernuitspraak gemaak dat die reg 'n "flankerende deelname" met betrekking tot hierdie diens het (BVerfGE 42, 312 (336)). Dit beteken dat die reg die verantwoordelikheid het om toe te sien dat die predikantsdiens ongehinderd tot uitvoering kom, én om die predikant teen "gevare en verhinderinge" wat in die pad van die predikant mag staan, te beskerm. Die reg mag in 'n mindere of meerdere mate aan hierdie verantwoordelikheid uitvoering gee, maar “... was immer es zum Schutz des Amtes zu regeln unternimmt, ist nach Auffassung der Kirche vom Amt her "gefordert"' (BVerfGE 42, 312 (336)). Die beskouing dat 'n predikant voltyds verantwoordelik is vir die predikantsdiens rus eweneens op die kerk se selfdefiniëring. Op grond van die kerk se selfdefiniëring het die kerk die reg om te bepaal dat 'n predikant nie ook 'n ander diens verrig nie.

Es kommt nicht darauf an, ob diese Unvereinbarkeit von kirchlichem und weltlichem Amt objektiv in jedem Fall, in dem ein Pfarrer Abgeordneter im Parlament wird, besteht oder nicht; es kommt vor allem nicht darauf an, ob dem Gericht einleuchtet, daß die Kirche um ihrer Glaubwürdigkeit und der Glaubwürdigkeit ihrer Diener willen die gleichzeitige Wahrnehmung von Pfarr- und Abgeordnetenmandat ausschließt; es kommt nur darauf an, daß die Kirche diese Regelung als von ihrem Selbstverständnis gefordert, für nötig halt. (BVerfGE 42, 312 $(336,337)$.)

\subsubsection{Wisselwerking tussen die kerkreg en die staatskerkreg}

Die Bundesverfassungsgericht wys daarop dat daar bykans geen aangeleentheid is wat volgens die kerke se selfdefiniëring nie ook 'n maatskaplike aspek (gesellschaftspolitischen Aspekt) bevat nie (BVerfGE 42, 312 (334)). Dit beteken dat die reëling van interne kerklike aangeleenthede ook juridiese gevolge het. Daar is selfs sekere aspekte van interne kerklike aangeleenthede, byvoorbeeld die wyse waarop die predikantsdiens gereël word, waarvoor die juridiese orde nodig is. Hierdie wisselwerking tussen die kerkregering en die staatsregering beteken egter nie dat die staat die kerklike reëlings, wat in die besonder die kerk se opdrag raak, mag begrens nie. So 'n begrensing sou die kerk se selfstandigheid teen- 
oor die staat in gedrang bring. Dit beteken ook dat die beperkingsklousule van die grondwet nie op die predikantsdiens van toepassing is nie. Die reëling van die predikantsdiens het ' $n$ direkte interne kerklike werking en slegs 'n indirekte uitwerking op die regstelsel. "Ihr steht also eine Schranke des für alle geltenden Gesetzes nicht entgegen." (BVerfGE 42, 312 (338).)

\subsection{Perspektief}

Die voorafgaande uiteensetting bied die volgende insigte:

- Die grense vir die staat se reëlingsbevoegdheid vir die predikantsdiens word nie in unieke reëlings van 'n regstelsel begrond nie. Hierdie grense word in algemeen geldende beginsels van die regstaat begrond. Dié beginsels sluit onder meer in dat die staat nie as 'n sogenaamde "oppergesag" die reg het om aan die kerk voor te skryf hoe die kerk gedefinieer behoort te word, of hoe die kerk moet funksioneer nie. Hierdie beginsels gee aan die kerk die reg om homself en die kerklike ampte te definieer. Die staat moet die selfdefiniëring van die kerk respekteer.

- Die grense vir die staat ten opsigte van die predikantsdiens word daardeur bepaal dat hierdie diens 'n uitvoering is van die kerk se Skrifbepaalde opdrag. Die kerk, en nie die staat nie, het die verantwoordelikheid vir die reëling van die predikantsdiens. Die staat se verantwoordelikheid is nie om die reëlingswyse vir predikantsdiens oor te neem nie. Die staat het die verantwoordelikheid om hierdie diens as interne kerklike aangeleentheid te beskerm. So skep die staat ruimte vir sy eie ontwikkeling.

- Die kerklike reëlings vir die predikantsdiens het ongetwyfeld regskonsekwensies. Die kerk se doel met die reëling van die predikantsdiens is egter nie gerig op die verwesenliking van 'n sekulêre doelstelling nie. Die reg het dus slegs 'n indirekte belang by die reëling van die predikantsdiens. Daarom mag die godsdiensneutrale staat nie die reëlings van hierdie diens uit eie oorweging oorneem nie.

\section{Grense tussen kerk en staat: gereformeerde benadering}

\subsection{Skrif}

Die grense vir die kerk en die staat se reëlingsbevoegdheid vir die predikantsdiens word volgens die gereformeerde kerkreg prinsipieel deur die Skrif bepaal. Verskeie tekste kan hiervoor as vertrekpunt 
dien. Hier val die fokus op Matteus 16:17-19. Op die vraag, "Maar wie sê julle is Ek?", antwoord Petrus as segsman van die apostels: "U is die Christus, die Seun van die lewende God." Waarop Jesus antwoord: "... Ek sê vir jou: Jy is Petrus, en op hierdie rots sal ek my kerk bou, en die magte van die doderyk sal dit nie oorweldig nie." Die belydenis van Petrus stel die grense tussen die kerk en die staat se reëlingsbevoegdheid. Dié belydenis skep as 't ware die ruimte vir die vestiging van 'n nuwe, georganiseerde gemeenskap. Die kerk word van ou-Israel, die menigte mense wat Jesus gevolg het en selfs van die staat en staatsregering onderskei (vgl. De Vaux, 1984:98, 99). Die kerk se eiesoortige bestaanswyse word in hierdie verse gedefinieer in terme van 'n teokratiese regeringswyse (Grosheide, 1954:257). Hierdie regeringswyse is geestelik en kan slegs in 'n kousale verband met die Koningskap van Christus verstaan word. Oor die kerk is slegs Christus Koning (Van der Linde 1965:76 e.v.).

In Matteus 16 ontvang die apostels die bevoegdheid om die sleutels van die koninkryk te bedien. Die futurum in Matteus 16:19 word telkens deur 'n perfektum passief in 'n perifrastiese konstruksie opgevolg (Vorster, 1999:49). Hierdie konstruksie impliseer dat wat Petrus op die aarde toesluit, sal in die hemel "reeds gesluit gewees het", en wat hy op die aarde oopsluit, sal in die hemel "reeds oopgesluit gewees het". Die regeringsdaad van Christus se geroepe diensknegte in die kerk op aarde, is dus reeds deur Homself in die hemel voltrek (Vorster, 1999:49). Hierdie regering vind uitdrukking by wyse van die verkondiging van die Woord en die bediening van die kerklike tug. (Die essensie van die kerklike tug is in wese Woordverkondiging. Juis deur die bediening van die Woord, die predikantsdiens, word 'n persoon voor Christus gestel; HK, Sondag 31.) Die grense vir die reëlingsbevoegdheid van die kerk en die godsdiensneutrale staat vind in 'n abstrakte sin vir sowel kerk as staat 'n begronding in die Koningskap van Christus oor die kerk. Die praktiese toepassing is dat die uitlewing van die kerk se opdrag, naamlik die Woordverkondiging, 'n grens stel aan die staat se reëlingsbevoegdheid. Slegs die kerk het die verantwoordelikheid vir die Woordverkondiging. Derhalwe behoort die predikantsdiens, wat die verantwoordelikheid het vir die Woordverkondiging, slegs deur die kerk gereël te word. Die godsdiensneutrale staat het nie die bevoegdheid om enige invloed op die predikantsdiens, en sodoende op die Woordverkondiging, uit te oefen nie. 


\subsection{Belydenis}

Die grense vir die reëlingsbevoegdheid van die staat vir die reëling van die predikantsdiens word eweneens deur die belydenisskrifte van die kerk bepaal (Smit \& Du Plooy, 2007:59-63). Die belydenisskrifte van die kerk verwoord die Skrifbeginsels waaraan die kerk glo. Die belydenisskrifte is dus nie 'n uitbreiding van die Skrif nie. Die Skrif is die norma normans wat die belydenis (die norma normata) volkome bepaal (Smit, 1984:62, 63). So is die belydenis in sy geheel 'n weerklank van die Skrif, of te wel, 'n nasê (homologein) van die Skrif (Polman, s.a:6, 7). Die belydenis stel, ooreenkomstig die Skrif, die roeping tot die predikantsdiens as die maatstaf vir die reëling en beoordeling van hierdie diens. Die belydenis sê dat 'n predikant moet wag totdat hy deur God geroep word, sodat hy van sy roeping oortuig kan wees en sekerheid kan hê dat dit van God kom (NGB, art. 31). Hieruit blyk dat die predikantsdiens deur God in Christus in die kerk gegee word. Die Een wat die bevoegdheid het om die diens te gee, het ook die bevoegdheid om die diens tot aksie te roep én die uitvoering van die diens te bepaal (vgl. Smit, 2001:2832). Die kerk, en nie die staat nie, het die uitsluitlike bevoegdheid om oor die roeping te oordeel en om die roeping te reël.

Die plek van die predikantsdiens én die wyse waarop die kerkregering gereël word, kom spesifiek in Artikels 28-31 van die Nederlandse Geloofsbelydenis na vore. Die predikantsdiens word verbind aan die geestelike bestuurswyse van die kerk (NGB, art. 30). In ooreenstemming met hierdie siening is predikante wat vir die predikantsdiens verantwoordelik is, bestuurders in die gemeenskap van die gelowiges. 'n Predikant is, saam met die ouderlinge, kubernéseis (stuurmanne) en hégoumenoi (leiers) wie se taak dit is om leiding in die gemeente te gee (proshistamenos) (Du Plooy, 1979: $54,55)$. Hierdie geestelike bestuurstaak vind daarin uitdrukking dat predikante nie heersers is nie, maar 'n voorbeeld vir die gelowiges; 'n herder; 'n dienskneg wat aan die Opperherder rekenskap moet gee - dus 'n rentmeester van God (Du Plooy, 1979:56). Die predikant ontvang die bevoegdheid en die bekwaamheid vir die uitvoering van die predikantsdiens van God.

Ten diepste is die predikant ook aan God verantwoording verskuldig vir die uitvoering van hierdie diens. Die predikantsdiens is dus ' $n$ belydenisbepaalde kerklike diens. Die godsdiensneutrale staat het nie die bevoegdheid om hierdie diens uit eie oorweging te reël nie. Indien die staat so ' $n$ benadering volg, beteken dit dat die staat gestalte gee aan die inhoud van die kerk se belydenis. Dit beteken dat die staat sy selfverklaarde godsdiensneutrale uitgangspunt 
versaak en nie die sogenaamde vryheidsregte wat deur alle hedendaagse grondwette gewaarborg word, tot uitvoer bring nie.

\subsection{Kerkorde}

Die kerkorde stel juis grense aan die kerk en die staat se reëlingsbevoegdheid vir die predikantsdiens. Die kerkorde, en hiermee ook die reëling van die predikantsdiens deur die kerkorde, is struktureel en inhoudelik gegrond op die belydenis (Hovius, 1962:22). Vanweë die verhouding tussen die kerkorde en die belydenis, waardeur die kerkorde die beginsels van die belydenis prakties in die Gereformeerde kerkorde reël, het die kerkorde die doel om die roeping van die predikante te reël (vgl. KO, art. 4, 5). Vanweë die roeping verbind die kerkorde die predikante in die eerste plek nie aan die kerk nie, maar aan die Hoofskap van Jesus Christus in die kerk. Sodoende is die predikantsdiens binne die raamwerk van die kerkorde deel van die kerk se geestelik-harmonieuse orde (Van't Spijker, 1990:157). Dit beteken dat die predikantsdiens integraal deel is van die ordelike bestaanswyse van die kerk in die wêreld (vgl. Van't Spijker, 1990:157). Hierdie bestaanswyse word vanuit die Skrif en die belydenis bepaal en word prakties by wyse van die kerkorde gereël.

Die uitgangspunt van Artikel 1 van die kerkorde wat in die Gereformeerde Kerke in Suid-Afrika toegepas word, stel die grense waarbinne die kerkordelike bepalings oor die predikantsdiens verstaan moet word. In Artikel 1 van die kerkorde word die volgende bepaal:

Om goeie orde in die kerk van Christus te onderhou, is daarin nodig: die dienste, samekomste, toesig oor die leer, sakramente en seremonies en die kerklike tug, waaroor hierna agtereenvolgens gehandel word.

Hierdie uitgangspunt benadruk dat dit die uitsluitlike doel van die Gereformeerde kerkorde is om reëlings vir die instandhouding en opbou van die kerk te tref (Calvyn, 1991:4.10.27; 4.11.1). Die kerk het volgens sy Skrifbepaalde orde nie die doel om op die reëlingsbevoegdheid van die staat te oortree nie. Die opdrag en taak van die kerk word deur die Skrif en die belydenis bepaal. Die belydenis (doctrina) en die regering (disciplina) van die kerk kan dus nie van mekaar geskei word nie. Dissipelskap is juis die gevolg van die verkondiging van die doctrina wat Christus aan ons geleer het (Du Plooy, 2002:4). Dit beteken dat die predikant se opdrag en taak gerig is op die opbou van die kerk en die uitbreiding van die koninkryk van die hemel. Hierdie opdrag en taak trek daarin saam 
dat die predikantsdiens sonder inmenging van die staat deur die geroepe dienaars uitgevoer moet word. Indien die godsdiensonpartydige staat die reëlingsbevoegdheid vir die predikantsdiens van die kerk oorneem, hou dit die moontlikheid in dat die staat inherent die beskermer van 'n verlossingsplan vir die burgerlike samelewing word.

\subsection{Perspektief}

Die voorafgaande uiteensetting bied die volgende insigte:

- Die grense vir die staat se reëlingsbevoegdheid vir die predikantsdiens rus daarop dat hierdie diens verantwoordelik is vir die uitvoering van die kerk se sentrale opdrag, naamlik die Woordverkondiging. Hierdie diens word eweneens eksegeties-dogmaties begrond.

- Die grense vir die staat se reëlingsbevoegdheid vir die predikantsdiens rus daarop dat die kerkordelike bepalings wat hierdie diens reël, uitdrukking is van die kerk se belydenis.

- Die grense vir die staat se reëlingsbevoegdheid vir die predikantsdiens rus daarop dat die kerk se selfstandige geloofsorde in gedrang kom indien die staat hierdie diens reël.

\section{Neerslag}

Die grens van die staat se bevoegdheid vir die predikantsdiens word in die hedendaagse regstaat, soos ook in Suid-Afrika, deur die grondwet bepaal. Hierdie grens het ontwikkel as gevolg van die Reformasie tydens die sestiende en sewentiende eeu. Hierdie ontwikkelingsgang het 'n neerslag in sowel die Duitse kerkregtradisie as die gereformeerde kerkregtradisie gelaat. Onafhanklik van mekaar en op verskeie maniere het die Skrifbepaalde bevoegdheid van die kerk na vore gekom, waarvolgens die staat erkenning moet gee aan die kerk se gesag om die predikantsdiens in eie (Skriftuurlike) terme te reël. Die staat, sowel as die kerk, mag hulleself nie die bevoegdheid veroorloof om enige seggenskap op die onderskeie gebiede van mekaar se opdragte en take uit te oefen nie.

Die predikantsdiens is die sentrale opdrag van die kerk en nie van die staat nie. Hierdie diens word eksegeties-dogmaties deur die kerk bepaal. Die kerk se reg om die predikantsdiens te reël, word by wyse van die sogenaamde "vryheidsregte" in die grondwet gewaarborg. Die "vryheidsregte" gee die geleentheid aan die kerk om homself en die kerklike ampte te definieer. Die draagwydte van 
hierdie regte behoort nie deur die spesifieke aard van 'n regstelsel ondergrawe te word nie. Derhalwe is die botsende uitsprake van Suid-Afrikaanse howe (kyk 1.2) onnodig. In hierdie artikel word die basiese raamwerk aangetoon waarvolgens howe die eiesoortige bevoegdheid van die kerk volkome behoort te erken, om reëlings oor kerklike sake op 'n kerklike wyse te tref, en om die geldigheid van kerkregtelike reëlings op grond van Skrifbepaalde gegewens te aanvaar - of in die regsorde te akkommodeer.

\section{Geraadpleegde bronne}

CALVYN, J. 1991. Institusie van die Christelike godsdiens. Boek 4. Vertaal deur H.W. Simpson. Potchefstroom: Calvyn Jubileum Boekefonds.

CODEX IURUS CANONICI. s.a. Münsterischer Kommentar zum Codex iuris canonici unter besonderer Berücksichtigung der Rechtslage in Deutchland, Österreich und der Schweiz. Hrsg. von Klaus Lüdecke unter Mitarb von Rudolf Henseler. Essen: Ludgerus.

COERTZEN, P. 2002. Church order or labour law: the position of ministers and others who work in the Dutch Reformed Church. European journal for church and state research - Revue européenne des relations Églises-État, 9:397-411.

DE BRES, G. 1561. Die Nederlandse geloofsbelydenis. (In Die berymde Psalms. Kaapstad: NG Kerk-Uitgewers. p. 488-516.)

DE VAUX, R. 1984. Ancient Israel: its life and institutions. Trans. by John McHugh. London: Darton, Longman \& Todd.

DU PLOOY, A. LE R. 1979. Ekklésia en meerdere vergaderinge. Potchefstroom: PU vir CHO. (M.A.-verhandeling.)

DU PLOOY, A. LE R. 2002. Kerke se interne verbandsreg en die arbeidswetgewing: advies aan die konvent van Gereformeerde Kerke in SuidAfrika. (Ongepubliseer.)

FRANK, J. 1976. Dienst und Arbeitsrecht in der evangelische Kirche: Essener Gespräche zum Thema Staat und Kirche. Münster: Aschendorf.

GROSHEIDE, F.W. 1954. Commentaar op het Nieuwe Testament: het heilig Evangelie volgens Mattheus. Kampen: Kok.

HECKEL, M. 1994. Die Verhältnis von Kirche und Staat nach evangelischem Verständnis. (In Listl, J. \& Pirson, D. Handbuch des Staatskirchenrecht der Bundesrepublik Deutschland. 1. Band. Berlin: Dunckler \& Humblot. S. 157-208.)

HESSE, K. 1994. Das Selbsbestimmungsrecht der Kirchen und Religionsgemeinschaften. (In Listl, J. \& Pirson, D. Handbuch des Staatskirchenrechts der Bundesrepublik Deutschland. 1. Band. Berlin: Dunckler \& Humblot. S. 521-559.)

$\mathrm{HK}$

kyk URSINUS, Z. \& OLEVIANUS, C.

HOLLERBACH, A. 1998. Religion und Kirche im freiheitlichen Verfassungsstaat: Schriftenreihe der juristischen Gesellschaft zu Berlin. Heft 156. Berlin: De Groot.

HOVIUS, J. 1962. Het verband tussen onze belijdenis en onze kerkorde. Smeek: Weissenbach. 
KERKORDEBOEKIE VAN DIE GEREFORMEERDE KERKE IN SUID-AFRIKA. 1998. Potchefstroom: Admin. Buro van die Gereformeerde Kerke in SuidAfrika.

KIRCHHOF, P. 1994. Die Kirchen und Religiongemeinschaften als Körperschaften des öffentlichen Rechts. (In Listl, J. \& Pirson, D. Handbuch des Staatskirchenrecht der Bundesrepublik Deutschland. 1. Band. Berlin: Dunckler \& Humblot. S. 651-687.)

$\mathrm{KO}$

kyk KERKORDEBOEKIE VAN DIE GEREFORMEERDE KERKE IN SUIDAFRIKA

NGB

kyk DE BRES, G.

OLIVIER, M. The South African Constitution and freedom of religion: some labour law imperatives and implications. Nederduitse Gereformeerde teologiese tydskrif, 43(3 \& 4):530-542.

PIRSON, D. 1994. Die geschichtlichen Wurzeln des deutschen Staatskirchenrechts. (In Listl, J. \& Pirson, D. Handbuch des Staatskirchenrechts der Bundesrepublik Deutschlands. 1. Band 2. grundlegend neubearbeitete Aufl. Berlin: Dunckler \& Humblot. S. 3-46.)

PIRSON, D. 1995. Das kircheneigene Diensrecht der Geistlichen und Kirchenbeampten. (In List, J. \& Pirson, D. Handbuch des Staatskirchenrechts der Bundesrepublik Deutschland. 2. Band. Berlin: Dunckler \& Humblot. S. 845-875.)

POLMAN, A.D.R. s.a. Onze Nederlandse geloofsbelijdenis: verklaard uit het verleden gekonfronteerd met de heden. Deel 4. Franeker: Wever.

RICHARDI, R. 2004. Arbeidsrecht in der Kirche: staatliches Arbeidsrecht und kirchliches Dienstrecht. 4. neu bearbeite Aufl. München: Beck.

ROBBERS, G. 2001. Religious freedom in Germany. Brigham Young University law review. http://lawreview.byu.edu/archives/2001 2.htm Date of access: 12 Apr. 2004.

RÜFNER, 1995. Individualrechtliche Aspekte des kirchlichen Dienst- und Arbeidsrechts: die besondere Loyalitätspflicht im kirclichen Dienst. (In Listl, J. \& Pirson, D. Handbuch des Staatskirchenrechts der Bundesrepublik Deutschland. 1. Band. Duncker \& Humblot: Berlin. S. 901-925.)

SCHLAICH, K. 1972. "Neutralität" als verfassungsrechtliches Prinzip. Tübingen: Mohr.

SMEND, R. 1951. Staat und Kirche nach dem Bonner Grundgesetz. Zeitschrift für evangelisches Kirchenrecht, 1:4-14.

SMIT, C.J. 1984. God se orde vir sy kerk. Pretoria: NG Kerkboekhandel.

SMIT, C.J. 1985. Kerkreg en kerkorde in die lig van God se reg vir sy kerk. Potchefstroom: PU vir CHO. (Th.D.-proefskrif.)

SMIT, C.J. 2008. Is die idee van 'n kerkorde nog kerklik byderwets? In die Skriflig, 42(2):225-238.

SMIT, J. 2001. 'n Gereformeerd-kerkregtelike beoordeling van die predikant se verbintenis aan die plaaslike kerk. Potchefstroom: $\mathrm{PU}$ vir $\mathrm{CHO}$. (Th.M.verhandeling.)

SMIT, J. \& DU PLOOY, A. LE R. 2008. Reëling van die Gereformeerde predikant se diens - 'n arbeidsregtelike of intere kerklike aangeleentheid? In die Skriflig, 42(1):51-74. 
URSINUS, Z. \& OLEVIANUS, C. 1563. Die Heidelbergse Kategismus of onderwysing in die Christelike leer. (In Die berymde Psalms. 1976. Kaapstad: NG Kerk-Uitgewers. p. 521-566.)

VAN DER LINDE, G.P.L. 1965. Die grondbeginsels van die presbiteriale kerkregering. Potchefstroom: Pro Rege.

VAN DER VYVER, J.D. 2002. The jurisprudential legacy of Abraham Kuyper and Leo XIII. Markets and morality, (5)1. http://www.acton.org/ publications/mandm/mandm_article_87.php Date of access: 3 Mar. 2009.

VAN DER WALT, J.J. 1976. Christus as Hoof van die kerk en die presbiteriale kerkregering. Potchefstroom: Pro Rege.

VAN'T SPIJKER, W. 1990. De kerk bij Calvijn: theocratie. (In Van't Spijker, W. et al. De Kerk: wezen, weg en werk van de kerk naar reformatorische opvatting. Kampen: De Groot Goudriaan. p. 143-162.)

VON CAMPENHAUSEN, A., Frhr. 1994. Der heutige Verfassungsstaat und die Religion. (In Listl, J. \& Pirson, D. Handbuch des Staatskirchenrechts der Bundesrepublik Deutschland. 1. Band. Berlin: Dunckler \& Humblot. S. 4784.)

VORSTER, N. 1999. Kerk en owerheid binne 'n regstaat: die roeping van die kerk met betrekking tot die Suid-Afrikaanse owerheid. Potchefstroom: PU vir CHO. (Th.M.-verhandeling.)

\section{Hofsake}

BVerfGE

kyk Entscheidungen des Bundesverfassungsgericht

Church of the Province of Southern Africa (Diocese of Cape Town) v. CCMA \& others [2001] 11 BLLR 1213 (LC)

Entscheidungen des Bundesverfassungsgericht 18, 385

Entscheidungen des Bundesverfassungsgericht 42, 312

Entscheidungen des Bundesverfassungsgericht 70, 138

Entscheidungen des Bundesverfassungsgericht (BverfG, BvR 1436/02 vom 3.6.2003)

Schreuder v. Die Nederduitse Gereformeerde Kerk Wilgespruit e.a. 199920 ILJ 1936 (LC)

\section{Kernbegrippe:}

belydenis van die kerk

godsdiensvryheid

grense vir kerk en staat

skeiding tussen kerk en staat

staatsneutraliteit/onpartydigheid

verkondigingsdiens 


\section{Key concepts:}

boundaries for church and state confessions of the church ministry of the Word religious freedom separation of church and state state neutrality/impartiality 